\title{
The Impact of Earnings Quality on Firm Value: The Case of Vietnam*
}

\author{
Hung Ngoc DANG ${ }^{* *}$, Thi Thu Cuc NGUYEN ${ }^{* * *}$, Dung Manh TRAN**** \\ Received: January 01, 2020 Revised: January 30, 2020 Accepted: February 06, 2020.
}

\begin{abstract}
The study aims to investigate the impact level of earnings quality on firm value. The study has used data with 3,910 observations at listed firms on Vietnam Stock Exchange for the period from 2010 to 2018, and GLS regression analysis is employed in this research. Earnings quality is measured in the aspects of earnings management, earnings persistence, and timeliness of profitability. This study also considers a number of controlled variables that positively influence the firm's value such as firm size, fixed asset investment rate and dividend payout ratio. The results show that earnings quality is positively associated with firm value with having statistical significance. In contrast, some determinants negatively influence firm value such as financial leverage, ratio of market value to book value, and revenue growth. Determinants of firm size, the rate of investment in fixed assets, the rate of dividend payment positively affect the firm value. In contrast, determinants of financial leverage, revenue growth rate and market value to book value ratio are inversely related to firm value according to economic value, Tobin's Q or Price. Based on the findings, some recommendations are proposed for investors, management and policy makers as well in the context of emerging countries including Vietnam.
\end{abstract}

Keywords: Earnings Quality, Firm Value, Earnings Management, Earnings Persistence.

JEL Classification Code: F65, G30, O16

\section{Introduction}

Earnings quality (EQ) of firms is an important determinant to minimize information asymmetry and thus promote the development of financial markets. EQ can be viewed as the potential profitability of the firms or the possibility that firm achieve the expected profit growth in the future. The value of a firm's stock, therefore, depends

*We gratefully acknowledge the financial support from the Vietnam National Foundation for Science and Technology Development (NAFOSTED) under Grant No. 502.02-2019.302.

**First Author. Associate Professor, Hanoi University of Industry, Vietnam [Postal Address: 298 Cau Dien Street, Bac Tu Liem District, Hanoi, 100000, Vietnam] Email: hungdangngockt@yahoo.com.vn ***Lecturer, Vinh University, Vietnam. Email: cucntt@vinhuni.edu.vn $* \star * \star$ Corresponding Author. Associate Professor, National Economics University, Vietnam [Postal Address: 207 Giai Phong Road, Hai Ba Trung District, Hanoi, 100000, Vietnam]

Tel: +84947120510 Email: manhdung@ktpt.edu.vn

(c) Copyright: The Author(s)

This is an Open Access article distributed under the terms of the Creative Commons Attribution NonCommercial License (https://creativecommons.org/licenses/by-nc/4.0/) which permits unrestricted noncommercial use, distribution, and reproduction in any medium, provided the original work is properly cited. not only on its earnings per share, but also on its future performance expectations and its reliability expectations on earnings.

Firm value is a topic that attracts a great deal of attention from firm executives and researchers, which determinants influence firm value? There have been a number of studies conducted such as Varaiya, Kerin, and Weeks (1987), Liow (2010), Hermuningsih (2014), Kodongo, MokoaleliMokoteli, and Maina (2015), Mule (2015), Sucuahi and Cambarihan (2016), Handoko (2017), and Nam (2019), who studied the impact of information on financial statements on firm value. The results of these studies have agreements and disagreements because of employing different techniques and measurements. In the information on the financial statements, EQ is a very important indicator that is interested by many stakeholders. In the context of Vietnam, there has not any comprehensive studies on the relationship and the impact of EQ on firm value. While research findings in the international contexts have inconsistent results, sometimes contradictory, on the other hand, the measure used to measure firm value is very diversified such as such as return on assets (ROA), return on equity (ROE), and earnings per share (EPS), Tobin's Q, 
economic value, stock price. The profitability of the reporting firms may not be true to the real profit of firm, the cause is due to the distortion of the declared profit of the firm arising from the conflict of interest between the manager and business owners and accounting constraints in the business such as errors in the forecasting process and estimation of future value or the use of inappropriate accounting methods make the difference between forecasted profits and profit in the financial statements.

The EQ is a reliable representation of the predicted profits and the declared profits, and the issued profits will be useful to users in making sound economic decisions. Richardson, Sloan, Soliman, and Tuna (2001) evaluated EQ basing on the persistence of future revenue and Beneish and Vargus (2002) also thought that the persistence of firm's revenue is will prove the business's EQ. Penman and Zhang (2002) defined EQ as the ability to forecast future income of a firm. Investors or stakeholders in the capital market often rely on information on the financial statements to evaluate the future cash flow of the firm from which to estimate the expected returns (Francis, LaFond, Olsson, \& Schipper, 2004). Thus, in order to better predict the future cash flow, the profit announced on the financial statements is a good quality profit. Based on literature review, it indicates that in a developing economy like Vietnam, there are incomplete legal regulations, business environment and stock market development, therefore conducting the impact of earnings quality on firm value will be of great significance.

\section{Theoretical Framework}

\subsection{Information Risks, Capital Costs and Firm Valuation}

From a financial perspective, the quality of financial information influences the firm's cost of capital in two ways, i.e. market liquidity or investor risk. On the one hand, high quality information can increase market liquidity by reducing transaction costs or increasing demand for securities investments (Amihud \& Mendelson, 1986; Diamond \& Verrecchia, 1991). On the other hand, since the decisions of rational investors largely depend on the quality and quantity of information available, investors will compensate for the information mismatches that could put them at higher risk by calculating the higher cost of capital (Easley \& O'hara, 2004; Leuz \& Verrecchia, 2005; Baimukhamedova, Baimukhamedova, \& Luchaninova, 2017).

Information risk in this case refers to the possibility that investors may decide in an uncertain manner because it is made basing on inadequate and less transparent firm specific information that could lead to investors pay additional investment costs. If the uncertainty is low, investors predict lower capital costs. By considering that the market value of firms is the present value through the present and future cash flows discounted at the riskadjusted capital cost, the low cost of capital shows a better value of the firm (Gaio \& Raposo, 2011).

Bushman and Smith (2001) identified three aspects that accounting information can affect capital costs. First, financial accounting needs to provide useful information, both directly to managers and investors, about investment opportunities and indirectly through contributing to the determination of stock prices reduces estimated risk, and thus reduces the firm's cost of capital. Second, financial accounting needs to provide useful information as a direct process of business control mechanisms, which will reduce risks, and thus reduce the firm's capital costs. Third, financial accounting information will contribute to reducing information mismatches between investors, this will reduce liquidity risks, and thus reduce the firm's capital costs. Furthermore, Leuz and Verrecchia (2005) showed that better quality information (or accurate reporting) improves the coordination between firms and investors on capital investment, reducing information risk and thus cut down the firm's cost of capital.

\subsection{Earnings Quality}

Profits are closely monitored by financial market participants, especially investors and analysts. Recent studies provide evidence that reported profits are a leading source of specific information for firms such as Francis et al. (2004), as they are a good indicator of future cash flows and there is more information about a firm's economic performance than cash (Dechow, 1994; Dechow, Kothari, \& Watts, 1998). Francis et al. (2004) examined the relationship between some attributes of profitability and cost of equity in the context of United States. They find that the properties of accounting-based profits (accruals quality, persistence, predictability) are significantly more cost effective than market-based attributes (relevance, value, timeliness and prudence) and accruals quality are the most valuable attributes. Bhattacharya, Daouk, and Welker (2003) found that the increase in profits, is defined as an aggregate measure of the positive level of income, avoiding losses and the stability of profits, is related to an increase in cost of equity and reduced transaction volume. There have been various studies in the US market (Bitner \& Dolan, 1996; Rountree, Weston, \& Allayannis, 2008) also investigate the relationship with EQ with firm valuation (Tobin'q measurement). Meanwhile, Bitner and Dolan (1996) examined the relationship between profitability and firm value. 


\section{Literature Review}

\subsection{Accruals Quality and Firm Value}

Unusual accruals are often used to justify profit management activities that demonstrate managerial opportunity behavior. The lower the content of the unusual accruals indicates that the reported earnings are less managed and can be presented as a business value. Profits reported with arbitrary high accruals are said to be of poor quality and less reliable and become one of the factors attributed to the investor's uncertainty especially with respect to the decision related to business valuation. Since profit information is relevant to the decision made, the accruals quality can be simply considered as the firm's indistinguishable information risk influencing the firm's capital costs. Consistently, Francis et al. (2005) described this concept when they declared that information risks, meaning that the firm's specific information ability in accordance with the investor's pricing decision is of poor quality. Because cash is an original factor that investors value, poor accruals quality suggests that the information about the profit-to-cash flow provided to investors is unclear, which can cause information risk and therefore the company's cost of capital is high (Francis et al., 2005). When considering the market value of firms called present value of current and future expected cash flows discounted at risk adjusted capital cost, low capital cost shows better value of the firm (Gaio \& Raposo, 2011).

\subsection{Earnings Predictability and Firm Value}

According to Lipe (1990), and Francis et al. (2004), predictive ability refers to the possibility of current reported profits to predict future profits. This particular profit attribute is viewed as the desired attribute of the process of setting standards and important components for valuing businesses by analysts (Francis et al., 2004). Some studies demonstrate the relevance of profit prediction in capital markets. Imhoff and Lobo (1992), and Pincus (1983) among others, proving the relationship between profit prediction and market reaction to profit announcements. In addition, Crabtree and Maher (2005) found a positive link between profitability and firm bond rating, besides the negative association between the ability to predict income and the cost of debt. Moreover, in relation to the actual cost of equity of the firm. Affleck-Graves, Callahan, and Chipalkatti (2002) found the effect of profitability predictability on the bid spread (a measure of cost of equity). They argue that the ability to predict low profits increases information asymmetry and increases trading opportunities to notify traders that can lead to an increase in adverse selection costs, and thus concludes that low capital cost for businesses with high anticipated profits.

\subsection{Prudent Principles and Firm Values}

Despite the opposition of capital market managers who set the standards and the scientific circles about the importance of the accounting prudence principle, we consider its implications for accounting. Business prices are based on previous documents. For example, Watts (2003), argued that contractual benefits, costs of asymmetric shareholder litigation, tax benefits and political pressure are determinants that demonstrate the importance of prudent principles. Kothari, Ramanna, and Skinner (2010) recognized the significance of accounting prudence in minimizing conflicts of representation of shareholders and managers. Institutional issues inherent in the relationship between shareholders and managers in public firms are likely to be reduced due to prudent accounting practices.

Kothari et al. (2010) suggested that accounting prudence reduces problems in three ways. First, because managers' compensation is directly linked to the company's performance, it is common for managers not willing to disclose bad news to avoid adversely affecting their current compensation, but conservative accountants give them the obligation to recognize and publish news promptly. Second, in the case of managers delaying the disclosure of bad news, managers tend to make risky investments in anticipation that will be exchanged with other indicators of performance. Prudent accounting then gives the shareholders timely signals and calls for them to act properly to avoid managers making such bad decisions. Third, prudent accounting also prevents shareholders from making excessive compensation to managers, as managers may be able to compensate themselves by delays in identifying bad news.

Based on the above arguments of Kothari et al. (2010) and previous studies, it can be argued that the quality of financial information has a direct impact on reducing firm capital costs (e.g., Easley \& O'hara, 2004; Leuz \& Verrecchia, 2005), specifically accounting prudence reduces capital costs and thus increases firm value in two ways. First, conservative accounting reduces the costs of agency conflicts and provides better future cash flow for shareholders that can reduce the cost of equity (Watts, 2003). Second, the prudent principle also reduces the information asymmetry that exists in the relationship between managers, as shareholders may require high capital costs for businesses to exercise low caution as the compensation for information less transparent for them (Ball, Kothari, \& Robin, 2000).

\subsection{Earnings Quality and Firm Value}


Gaio and Raposo (2011) conducted a study using a sample of more than 7,000 observations in firms in 38 countries considering the relationship between EQ and firm value (Tobin's Q). The results show a positive and meaningful relationship between EQ and business value, in which the aggregate income quality measure is based on seven income attributes (accruals quality, persistence, predictability, stability, relevance, timeliness and prudence). Hutagaol-Martowidjojo, Valentincic, and Warganegara (2019) showed that EQ is negatively correlated with the market value of equity of firms listed on the Jakarta Stock Exchange. Latif, Bhatti, and Raheman (2017) conducted a study of 214 non-financial listed firms in Pakistan between 2003 and 2014, and fond that EQ contributed positively to maximizing firm value.

Based on literature review, there have been several studies on EQ in terms of accruals quality, prudent principles or general EQ influencing form value. In this study, we continue to look at other aspects of EQ such as earnings management, earnings persistence and the timeliness of profit information influencing firm value.

\section{Research Methodology}

\subsection{Firm Value Measurement}

If the firm is considered as an investment asset, its value depends on the income it brings to the investor. Therefore, firm value is the total present value of all income that is likely to be generated during the course of a business operation. In other words, firm value is the existing benefits and the potential benefits that a firm can generate are expressed in the form of value that we can determine through the suitable methods and pricing model. To decide the firm value, there are many different approaches and accesses. In general, these methods focus primarily on the following three views:

Viewpoints based on assets are the views on determining the firm value on the basis of the balance sheet. Leland and Toft (1996) state that the firm is equal to the value of assets plus the benefits of the tax shield from debt minus the cost of bankruptcy related to debt. Pandey (2004) supposes that defined firm value is viewed as the total value of all its securities. Modigliani and Johnson (1980) defined in the way that firm value is understood as equal to the total debt and equity if the firm has financial leverage (using longterm debt); Firm value is only equal to the value of equity if the firm does not have financial leverage (do not use longterm debt). Based on the view of Modigliani and Johnson (1980), Antwi, Mills, and Zhao (2012), and Maxwell and Kehinde (2012) have identified corporate value as:
Firm value $=$ Market capitalization of Equity + Longterm debt with interest

Viewpoints based on financial performance are the views on valuing enterprises on the basis of reporting business results. This is a method of determining the value of a firm depended on the perspective of capital mobilization with the expectation of increasing the value of equity, meaning the increase in the firm value. According to La Rocca (2010), with a sample of 36 studies in the period of 19882006 selected for the survey, about $33 \%$ of the studies used return on assets (ROA) and return on equity (ROE) indicators on behalf of firm value and $67 \%$ of studies used Tobin's q and other indicators such as earnings per share (EPS), economic value added (EVA) and others to represent the firm value. The Tobin's Q index, according to Chung and Pruitt (1994), Lin (2010) is determined as below:

Tobin's Q

$$
\text { Market capitalization }+ \text { Preferred }
$$

$$
\text { stock value }+ \text { Net debt }
$$

Market-based viewpoint: the point of view of determining the firm value on the market share price. La Porta, Lopez-de-Silanes, Shleifer, and Vishny (2000), Ball et al. (2000), Morck, Shleifer, and Vishny (1988) determined that the influence of business information on stock prices is less than in countries where the weak rule of law protects investor rights. Because the stock price often reflects a firm's expectations, its market value can significantly affect the firm's true value if it can provide enough relevant information. The smaller the standard deviation is the stock price, the lower the risk of investment. However, the volatility of stock prices has a significant impact on investment decisions, so research through market value of stocks is a measure of firm value.

\subsection{Earnings Quality Measurement}

This study measures EQ on such aspects as profit management, persistence, and timeliness of profit information. The measurement of the components of the EQ is shown as follows:

Earnings quality measured through earnings management: There are various ways to measure the quality of profits through extraordinary accrual/earnings management (EM), we employ the model of Jones (1991). Earnings management variable measured through proxy is the remainder of equation (1). The EQ is the opposite of the remainder of the following equation:

$\mathrm{ACCit}=\beta 0+\beta 1(\mathrm{REVit}-\mathrm{ARit})+\beta 2 \mathrm{PPEit}+\varepsilon \mathrm{it}$ 
In which:

$\triangle R E V_{i t}$ is the difference between revenue of firm $\mathrm{i}$ in year $\mathrm{t}$ and year $\mathrm{t}-1$

$P P E_{i t}$ is the cost of fixed assets of firm $\mathrm{i}$ in year $\mathrm{t}$

$A_{i t-1}$ is total assets of year $\mathrm{t}-1$

$\alpha_{1}, \alpha_{2}, \alpha_{3}$, are the parameters of each firm

The earnings management (EM) will be taken as a residual of eit because the earnings management is an earnings-adjusting behavior, so whether the adjustment is increased or decreased (equivalent to the adjusted accruals variable with negative values or positive) are all behaviors. Thus, eit is the measurement of earnings management variable (earnings quality), the higher the deviation cit, the lower earnings quality. Earnings quality is measured by earnings management is defined:

$$
\mathrm{EQ} \_\mathrm{EM}=\mathrm{EM}^{*}(-1) \text {. }
$$

Earnings quality is measured through the persistence of profits: Li et al. (2014) implemented EQ in terms of persistence. For the persistence of profit (earnings persistence), he based on the research of Kormendi and Lipe (1987) which used the regression results of the model (4) between current profit and previous year's profit, regression coefficients are estimated from the model to measure the persistence of profits.

$\frac{\text { Earnit }}{A_{i t-1}}=\alpha+\alpha_{1} \frac{\text { Earnit-1 }}{A_{i t-1}}+$ cit

Earnit is the net profit of firm $i$ before extraordinary amounts in year $t$.

Earnit-1 is the net profit of firm i before extraordinary amounts in year $\mathrm{t}-1$.

eit is the error number

To measure the EQ according to the persistence of profit, EQ is determined based on the regression results from equation (3). Proxy variables reflect EQ_PE as the R2 coefficient of the equation (4):

$$
\text { EQ_AQ }=\text { PERS }
$$

Profit quality measured through the timeliness of profits: Based on the model of Basu (1997), stock prices are determined on the basis of combining all information in the market in a timely manner from a variety of sources, including firm earnings reports. Therefore, changes in stock prices are the criteria for assessing the news obtained in each period. Meanwhile, firm earnings reports are influenced by asymmetry in timely recording of information - often receiving bad information faster than good information. Basu's regression function is as follows:

$$
\text { EARNit }=\beta 0+\beta 1 \text { NEGit }+\beta 2 \text { RETit }+\beta 3 \text { NEGit } * \text { RETit }+
$$
Eit
In which:

$\beta 0=$ Intercept;

$\beta 1, \beta 2, \beta 3$ : The coefficients;

EARNit: Profit per share of firm i in year t;

RETit: is the share yield of firm $i$ in year $t$;

NEGit is a dummy variable with value $=1$ in case of good information;

NEGit is dummy variable with value $=0$ in case of bad information;

The gradient (slope) of the model represents the degree of asymmetry of timeliness in recording information into the firm's profit value. The timeliness of profit information (TIMEL) is positively correlated and the coefficient R2 is determined from equation (3). The higher value of timeliness (TIMEL) implies more timely profits and higher quality of returns. Profits reflect information integrated into stock returns faster than investors perceive it to be of higher quality. The variable of earnings quality measured by timeliness is defined EQ_TI = TIMEL.

\subsection{Model and Research Data}

From the literature review and hypotheses, we design a

\begin{tabular}{|c|c|c|c|}
\hline Variables & Codes & Measurement & $\begin{array}{c}\text { Impact } \\
\text { direction }\end{array}$ \\
\hline Firm value & $\begin{array}{c}\mathrm{FV}_{-} \\
\text {Tobin } \\
\text { FV } \\
\text { EV } \\
\text { FV } \\
\text { PRICE }\end{array}$ & $\begin{array}{c}\text { FV_Tobin= }(\text { Market } \\
\text { capitalization }+ \\
\text { Liabilities }) / \text { Total assets } \\
\text { FV_EV }=\text { Ln(Market } \\
\text { capitalization + Long-term debt } \\
\text { with interest }- \text { Cash and cash } \\
\text { equivalents) } \\
\text { FV_PRICE }=\text { log(Stock price } \\
\text { of firm at the end of year t) }\end{array}$ & \\
\hline $\begin{array}{l}\text { Earnings } \\
\text { managemen } \\
\mathrm{t}\end{array}$ & $\begin{array}{l}\mathrm{EQ} \\
\mathrm{EM}\end{array}$ & $\begin{array}{l}\text { The absolute value of the } \\
\text { residuals from the equation, } \\
\text { multiplied by }(-1): \mathrm{ACC}_{\mathrm{it}}=\alpha+ \\
\beta_{1}\left(\mathrm{REV}_{\mathrm{it}}-\mathrm{AR}_{\mathrm{it}}\right)+\beta_{2} \mathrm{PPE}_{\mathrm{it}}+\varepsilon_{\mathrm{it}}\end{array}$ & + \\
\hline $\begin{array}{l}\text { Earnings } \\
\text { persistence }\end{array}$ & $\begin{array}{l}\text { EQ } \\
\text { PERS }\end{array}$ & $\begin{array}{c}\text { The level of explanation } \mathrm{R}^{2} \text { of } \\
\text { the equation: } \text { EARN }_{\mathrm{it}}=\alpha+ \\
\qquad \beta \mathrm{EARN}_{\mathrm{it}-1}+\varepsilon_{\mathrm{it}}\end{array}$ & + \\
\hline Timeliness & $\begin{array}{l}\text { EQ } \\
\text { TIME }\end{array}$ & $\begin{array}{c}\text { The level of explanation } \mathrm{R}^{2} \text { of } \\
\text { the equation: } \\
\mathrm{EARN}_{\mathrm{it}}=\beta_{0}+\beta_{1} \mathrm{NEG}_{\mathrm{it}}+\beta_{2} \mathrm{RET}_{\mathrm{it}}+ \\
\beta_{3} \mathrm{NEG}_{\mathrm{it}}{ }^{*} \mathrm{RET}_{\mathrm{it}}+\varepsilon_{\mathrm{it}}\end{array}$ & + \\
\hline Firm size & SIZE & $\begin{array}{c}\text { The size of the firm by assets } \\
\text { Log (Total Asset) }\end{array}$ & + \\
\hline $\begin{array}{l}\text { Financial } \\
\text { leverage }\end{array}$ & LV & Liabilities/Total assets & - \\
\hline
\end{tabular}
research model as below (see Table 1):

Table 1: Describe the variables in the research model 


\begin{tabular}{|c|c|c|c|}
\hline Variables & Codes & Measurement & $\begin{array}{c}\text { Impact } \\
\text { direction }\end{array}$ \\
\hline $\begin{array}{c}\text { The ratio of } \\
\text { market } \\
\text { value to } \\
\text { book value }\end{array}$ & BM & Market value/Book value & - \\
\hline Growth & $\begin{array}{c}\text { GROW } \\
\text { T }\end{array}$ & $\begin{array}{c}\text { (Revenue period } \mathrm{t} \text { - revenue } \\
\text { period t-1)/Revenue period t-1 }\end{array}$ & - \\
\hline $\begin{array}{c}\text { Fixed asset } \\
\text { investment } \\
\text { rate }\end{array}$ & PPET & $\begin{array}{c}\text { Net book value of fixed assets / } \\
\text { Total assets }\end{array}$ & + \\
\hline $\begin{array}{c}\text { Dividend } \\
\text { payment } \\
\text { ratio }\end{array}$ & DY & $\begin{array}{r}\text { Dividend payment ratio on par } \\
\text { value }\end{array}$ & + \\
\hline
\end{tabular}

FVit $=\beta 0+\beta 1$ EQit $+\beta 2$ SIZEit $+\beta 3$ LVit $+\beta 4$ BMit $+\beta 5-$ GROWTit $+\beta 6$ PPETit $+\beta 7$ DYit $+\varepsilon$ it

This research uses data from Vietnam Stock Exchange Market in the period from 2010 to 2018. Data were collected from audited financial statements of listed firms after excluding firms in the field of banks, securities, and insurance. After determining the indicators, the data used for analysis and regression were 3,910 observations. We employ GLS regression to overcome the regression model's defects such as autocorrelation and variance change.

\subsection{Research Hypotheses}

When considering the firm market value called present value of current and future expected cash flows discounted at risk adjusted capital cost, low capital cost shows better value of companies (Gaio \& Raposo, 2011). Based on the studies of Gaio and Raposo (2011), Lu (2012), Latif et al. (2017), Dang, Vu, Ngo, and Hoang (2019), and Hutagaol et al. (2019), we propose a hypothesis that has a positive relationship trend between EQ and firm value.

\section{Results and Discussion}

Data in Table 2 show that firm value measured by Tobin' $Q$ has an average value of 1,061 , while the firm value is measured by economic value, the stock price after logarithms have the average values are 26.269 and 9.466. The average EQ for each aspect such as earnings management (EQ_EM) is 0.204 , the persistence of earnings (EQ_ PERS) is 0.844 and the timeliness of information (EQ TIME) is 0.122. Firm size is measured by the logarithm value of the average total assets of 27,085. Financial leverage of firm is measured as the ratio of liabilities to total assets with an average value of 0.498 , average revenue growth rate of $14.7 \%$, the average rate of investment in fixed assets is $19.3 \%$ and the dividend payout ratio is $9.7 \%$.

Table 2: Descriptive statistics

\begin{tabular}{|l|c|c|c|c|c|}
\hline Variables & $\begin{array}{c}\text { No. of } \\
\text { observations }\end{array}$ & Average & $\begin{array}{c}\text { Standard } \\
\text { deviation }\end{array}$ & Min & Max \\
\hline FV_Tobin & 3,910 & 1.061 & 0.552 & 0.100 & 6.124 \\
\hline FV_EV & 3,910 & 26.269 & 1.642 & 21.692 & 32.543 \\
\hline FV_PRICE & 3,910 & 9.466 & 0.969 & 5.704 & 12.128 \\
\hline EQ_EM & 3,910 & 0.204 & 1.779 & -6.892 & 10.693 \\
\hline EQ_PERS & 3,910 & 0.844 & 0.158 & 0.609 & 1.128 \\
\hline EQ_TIME & 3,033 & 0.122 & 0.074 & 0.023 & 0.224 \\
\hline SIZE & 3,910 & 27.085 & 1.438 & 23.659 & 30.915 \\
\hline LV & 3,880 & 0.498 & 0.213 & 0.038 & 0.914 \\
\hline BM & 3,910 & 2.114 & 1.444 & 0.256 & 9.470 \\
\hline GROWT & 3,864 & 0.147 & 0.510 & -0.756 & 6.771 \\
\hline PPET & 3,855 & 0.193 & 0.186 & 0.000 & 0.836 \\
\hline DY & 3,895 & 0.097 & 0.115 & 0.000 & 0.761 \\
\hline
\end{tabular}

Table 3, showing the correlation coefficients between variables, the purpose of examining the close correlation between the independent and dependent variables to eliminate determinants that may lead to multicollinearity before running regression model. The relationship between the dependent variable is the firm value and the independent variable is the profit EQ from each aspect shows that there are statistical significance levels. The correlation coefficient between the independent variables in the model does not have any pair greater than 0.8 , so it is less likely to have multi-collinear phenomena. We use VIF coefficient to check when using the regression model.

Based on Table 4, EQ is measured in terms of earnings management, earnings persistence, and timeliness of profit information with a positive and statistical relationship of $1 \%$ to the firm value. Thus raising EQ would contribute to increase the firm value. The results of this study are in agreement with those of Gaio and Raposo (2011), and Latif et al. (2017). For the control variable, which is the firm size, the rate of investment in fixed assets, the dividend payment ratio is positively related to the firm value and is statistically significant at $1 \%$. This study is in agreement with those of Colquitt et al. (1999), Liebenberg and Hoyt (2003), Dang et al. (2019), Dang et al. (2018), and Nguyen et al. (2019). Meanwhile, determinants of financial leverage, growth rate, and market value ratio on the books are inversely related to the firm value. This research is in agreement with the results of Modigliani and Miller (1958), and Modigliani and Miller (1963) 
Table 3: Correlation matrix

\begin{tabular}{|c|c|c|c|c|c|c|c|c|c|c|c|c|}
\hline & FV_Tobin & FV_EV & FV_PRICE & EQ_EM & EQ_PERS & EQ_TIME & SIZE & $\mathbf{L V}$ & BM & GROWT & PPET & DY \\
\hline FV_Tobin & 1 & & & & & & & & & & & \\
\hline FV_EV & $0.3376^{*}$ & 1 & & & & & & & & & & \\
\hline FV_PRICE & $0.6900^{*}$ & $0.4554^{*}$ & 1 & & & & & & & & & \\
\hline EQ_EM & $0.0736^{*}$ & -0.0007 & $0.1229^{*}$ & 1 & & & & & & & & \\
\hline EQ_PERS & 0.0166 & $-0.0433 *$ & -0.0067 & $0.0420^{*}$ & 1 & & & & & & & \\
\hline EQ_TIME & $0.0445^{*}$ & $-0.0588^{*}$ & 0.0026 & $0.0446^{*}$ & $0.3843^{*}$ & 1 & & & & & & \\
\hline SIZE & $-0.0443^{*}$ & $0.8438^{*}$ & $0.0483 *$ & -0.0265 & $-0.0429 *$ & $-0.0754^{*}$ & 1 & & & & & \\
\hline LV & $-0.1486^{*}$ & $0.0331^{*}$ & $-0.1680^{*}$ & $0.0612 *$ & $0.0447 *$ & 0.0256 & $0.3145^{*}$ & 1 & & & & \\
\hline $\mathrm{BM}$ & $-0.2768^{*}$ & $-0.2706^{*}$ & $-0.3202 *$ & 0.0048 & $0.2300^{*}$ & $0.2232 *$ & $-0.0804 *$ & $0.1533^{*}$ & 1 & & & \\
\hline GROWT & -0.0077 & $0.0686^{*}$ & 0.002 & $0.4663^{*}$ & -0.0211 & 0.0021 & $0.0798^{*}$ & 0.0159 & $-0.0341^{*}$ & 1 & & \\
\hline PPET & $0.0941^{*}$ & $0.1465^{*}$ & $0.0495 *$ & $-0.0659^{*}$ & 0.0084 & -0.0052 & 0.0108 & $-0.0572 *$ & $-0.0517^{*}$ & $-0.0513^{*}$ & 1 & \\
\hline DY & $0.1004^{*}$ & $-0.0688^{*}$ & $0.2200^{*}$ & $0.1505^{*}$ & $0.2056^{*}$ & $0.2466^{*}$ & $-0.1352^{*}$ & 0.0252 & $0.3279^{*}$ & 0.0165 & 0.0117 & 1 \\
\hline
\end{tabular}

Table 4: Multivariate regression results

\begin{tabular}{|c|c|c|c|c|c|c|c|c|c|}
\hline & FV_Tobin & FV_Tobin & FV_Tobin & FV_EV & FV_EV & FV_EV & FV_PRICE & FV_PRICE & FV_PRICE \\
\hline \multirow[t]{2}{*}{ EQ_EM } & $0.0278 * *$ & & & $0.0413 * *$ & & & $0.0713 * * *$ & & \\
\hline & [5.11] & & & [5.82] & & & [8.12] & & \\
\hline \multirow[t]{2}{*}{ EQ_PERS } & & $0.204 * * *$ & & & $0.292 * * *$ & & & 0.148 * & \\
\hline & & [3.72] & & & [4.07] & & & [1.66] & \\
\hline \multirow[t]{2}{*}{ EQ_TIME } & & & $0.591 * * *$ & & & $0.790 * * *$ & & & $0.409 *$ \\
\hline & & & [4.61] & & & {$[4.75]$} & & & [1.96] \\
\hline \multirow[t]{2}{*}{ SIZE } & -0.000997 & -0.00301 & -0.000547 & $1.052 * * *$ & $1.049 * * *$ & $1.052 * * *$ & $0.0844 * * *$ & $0.0786 * * *$ & $0.0799 * * *$ \\
\hline & {$[-0.16]$} & {$[-0.48]$} & {$[-0.08]$} & [129.27] & [128.95] & [119.47] & [8.39] & {$[7.77]$} & {$[7.22]$} \\
\hline \multirow[t]{2}{*}{ LV } & $-0.285 * * *$ & $-0.270 * * *$ & $-0.261 * * *$ & $-1.768 * * *$ & $-1.744 * * *$ & $-1.767 * * *$ & $-0.766 * * *$ & $-0.721 * * *$ & $-0.687 * * *$ \\
\hline & {$[-6.78]$} & {$[-6.42]$} & {$[-5.73]$} & {$[-32.15]$} & {$[-31.76]$} & {$[-29.90]$} & {$[-11.26]$} & {$[-10.55]$} & {$[-9.26]$} \\
\hline \multirow[t]{2}{*}{$\mathrm{BM}$} & $-0.131 * * *$ & $-0.137 * * *$ & $-0.150 * * *$ & $-0.236 * * *$ & $-0.245 * * *$ & $-0.280 * * *$ & $-0.288 * * *$ & $-0.296 * * *$ & $-0.348 * * *$ \\
\hline & {$[-20.43]$} & {$[-21.05]$} & {$[-20.53]$} & {$[-28.32]$} & {$[-28.90]$} & {$[-29.61]$} & {$[-27.93]$} & {$[-28.05]$} & {$[-29.25]$} \\
\hline \multirow[t]{2}{*}{ GROWT } & $-0.0685 * * *$ & -0.0208 & -0.0234 & $-0.0927 * * *$ & -0.0217 & -0.0315 & $-0.173 * * *$ & $-0.0530 *$ & -0.0695 \\
\hline & {$[-3.61]$} & {$[-1.25]$} & {$[-1.30]$} & {$[-3.74]$} & {$[-1.00]$} & {$[-1.35]$} & {$[-5.65]$} & {$[-1.95]$} & {$[-2.36]$} \\
\hline \multirow[t]{2}{*}{ PPET } & $0.209 * * *$ & $0.195 * * *$ & $0.175 * * *$ & $0.972 * * *$ & $0.951 * * *$ & $0.917 * * *$ & 0.0882 & 0.0572 & 0.028 \\
\hline & [4.64] & [4.32] & {$[3.51]$} & {$[16.48]$} & [16.10] & {$[14.24]$} & {$[1.21]$} & {$[0.78]$} & {$[0.35]$} \\
\hline \multirow[t]{2}{*}{ DY } & $0.955 * * *$ & $0.978 * * *$ & $0.962 * * *$ & $1.774 * * *$ & $1.811 * * *$ & $1.907 * * *$ & $2.990 * * *$ & $3.123 * * *$ & $3.164 * * *$ \\
\hline & {$[12.21]$} & [12.53] & {$[11.00]$} & [17.37] & {$[17.75]$} & {$[16.83]$} & [23.67] & [24.60] & {$[22.23]$} \\
\hline \multirow[t]{2}{*}{ _cons } & $1.375 * * *$ & $1.262 * * *$ & $1.305^{* * *}$ & $-1.198 * * *$ & $-1.356^{* * *}$ & $-1.253 * * *$ & $7.876^{* * *}$ & $7.894 * * *$ & $7.996^{* * *}$ \\
\hline & [8.31] & [7.36] & [7.17] & {$[-5.54]$} & {$[-6.06]$} & {$[-5.32]$} & [29.47] & [28.33] & {$[27.00]$} \\
\hline $\mathrm{N}$ & 3769 & 3769 & 2918 & 3769 & 3769 & 2918 & 3769 & 3769 & 2918 \\
\hline
\end{tabular}

Note: $\mathrm{t}$ statistics in brackets $* \mathrm{p}<0.1, * * \mathrm{p}<0.05, * * * \mathrm{p}<0.01$ 


\section{Conclusion and Recommendations}

With empirical results, we have used data with 3,910 observations at listed firms on Vietnam' Stock Exchange for the period from 2010 to 2018, and GLS regression analysis is employed in this research. The study investigated the impact level of earnings quality on firm value. The results show that EQ is measured in terms of earnings management, the persistence of earnings and the timeliness of earnings information that positively influence firm value. Determinants of firm size, the rate of investment in fixed assets, the rate of dividend payment positively affect the firm value. In contrast, determinants of financial leverage, revenue growth rate and market value to book value ratio are inversely related to firm value according to economic value (EV), Tobin's Q or Price.

Based on the findings together with in-depth interviews of management of listed firms on Vietnam Stock Exchange, some recommendations are given as:

First, the government needs to develop management mechanisms, pressuring businesses to make, present and disclose financial statements in the expression of true and fair value. The processes should be strictly controlled, have sanctions against firms that violate and protect the rights of investors. Moreover, building and creating a stock market of active and sustainable development, having access to international practices are other tasks that should be regulated.

Second, firms should be aware of the importance of having their financial statements by preparing, issuing reliable financial statements. By doing this will help investors be aware of which firms develop well through the aspects of EQ to firm value, there will be appropriate investment direction to avoid risks and firms will reduce the cost of capital.

Third, firms should expand the form of joint venture, cooperate with partners both local and international partners to have more assets, especially fixed assets with modern technology to operate as well as take advantage of management skills, management assets and market of partners to enhance firm value. In addition, firms need to manage well the costs related to sales and business management along with good governance of receivables, contributing to improving financial performance.

Fourth, financial leverage has a negative impact on the firm value. This means that firms with more debt will reduce the profitability ratio, so firms need to be very careful in raising loans, prioritizing equity, and issuing stock.

\section{References}

Affleck-Graves, J., Callahan, C. M., \& Chipalkatti, N. (2002). Earnings predictability, information asymmetry, and market liquidity. Journal of Accounting Research, 40(3), 561-583.

Amihud, Y., \& Mendelson, H. (1986). Asset pricing and the bidask spread. Journal of Financial Economics, 17(2), 223-249.

Antwi, S., Mills, E. F. E. A., \& Zhao, X. (2012). Capital structure and firm value: Empirical evidence from Ghana. International Journal of Business and Social Science, 3(22), 103-111.

Baimukhamedova, A., Baimukhamedova, G., \& Luchaninova, A. (2017). Financial disclosure and the cost of equity capital: The empirical test of the largest listed companies of Kazakhstan. Journal of Asian Finance, Economics and Business, 4(3), 5-17. http://dx.doi.org/10.13106/jafeb.2017.vol4.no3.5.

Ball, R., Kothari, S., \& Robin, A. (2000). The effect of international institutional factors on properties of accounting earnings. Journal of Accounting and Economics, 29(1), 1-51.

Basu, S. (1997). The conservatism principle and the asymmetric timeliness of earnings. Journal of Accounting and Economics, 24(1), 3-37.

Beneish, M. D., \& Vargus, M. E. (2002). Insider trading, earnings quality, and accrual mispricing. The Accounting Review, 77(4), 755-791.

Bhattacharya, U., Daouk, H., \& Welker, M. (2003). The world price of earnings opacity. The Accounting Review, 78(3), 641678.

Bitner, L. N., \& Dolan, R. C. (1996). Assessing the relationship between income smoothing and the value of the firm. Quarterly Journal of Business and Economics, 35, 16-35.

Bushman, R. M., \& Smith, A. J. (2001). Financial accounting information and corporate governance. Journal of Accounting and Economics, 32(1-3), 237-333.

Chung, K. H., \& Pruitt, S. W. (1994). A simple approximation of Tobin's q. Financial Management, 23(3), 70-74.

Colquitt, L. L., Hoyt, R. E., \& Lee, R. B. (1999). Integrated risk management and the role of the risk manager. Risk Management and Insurance Review, 2(3), 43-61.

Crabtree, A. D., \& Maher, J. J. (2005). Earnings predictability, bond ratings, and bond yields. Review of Quantitative Finance and Accounting, 25(3), 233-253.

Dang, H. N., Vu, V. T. T., Ngo, X. T., \& Hoang, H. T. V. (2019). Study the impact of growth, firm size, capital structure, and profitability on enterprise value: Evidence of enterprises in Vietnam. Journal of Corporate Accounting \& Finance, 30(1), 144-160.

Dang, N. H., Pham, D. C., \& Vu, T. B. H. (2018). Effects of financial statements information on firms' value: evidence from Vietnamese listed firms. Investment Management and Financial Innovations, 15(4), 210-218.

Dang, N. H., Tran, B. M., \& Tran, M. D. (2019). Impact of Dividend Policy on Variation of Stock Prices: Empirical Study of Vietnam. Journal of Economics and Development, 21(Special Issue), 96-106.

Dang, N. H., Hoang, T. T. H. \& Dinh, T. B. (2018). Impact of accounting information on financial statements to the stock price of the energy enterprises listed on Vietnam's stock market. International Journal of Energy Economics and Policy, $8(2), 1-6$. 
Dechow, P. M. (1994). Accounting earnings and cash flows as measures of firm performance: The role of accounting accruals. Journal of Accounting and Economics, 18(1), 3-42.

Dechow, P. M., Kothari, S. P., \& Watts, R. L. (1998). The relation between earnings and cash flows. Journal of Accounting and Economics, 25(2), 133-168.

Diamond, D. W., \& Verrecchia, R. E. (1991). Disclosure, liquidity, and the cost of capital. The Journal of Finance, 46(4), 13251359.

Easley, D., \& O'hara, M. (2004). Information and the cost of capital. The Journal of Finance, 59(4), 1553-1583.

Francis, J., LaFond, R., Olsson, P., \& Schipper, K. (2005). The market pricing of accruals quality. Journal of Accounting and Economics, 39(2), 295-327.

Francis, J., LaFond, R., Olsson, P. M., \& Schipper, K. (2004). Costs of equity and earnings attributes. The Accounting Review, 79(4), 967-1010.

Gaio, C., \& Raposo, C. (2011). Earnings quality and firm valuation: international evidence. Accounting \& Finance, 51(2), 467-499.

Hermuningsih, S. (2014). Profitability, Growth Opportunity, Capital Structure and the Firm Value. Bulletin of Monetary Economics and Banking (Buletin Ekonomi Moneter dan Perbankan), 16(2), 115-136.

Hutagaol-Martowidjojo, Y., Valentincic, A., \& Warganegara, D. L. (2019). Earnings Quality and Market Values of Indonesian Listed Firms. Australian Accounting Review, 29(1), 95-111.

Imhoff Jr, E. A., \& Lobo, G. J. (1992). The effect of ex ante earnings uncertainty on earnings response coefficients. Accounting Review, 427-439.

Kodongo, O., Mokoaleli-Mokoteli, T., \& Maina, L. N. (2015). Capital structure, profitability and firm value: panel evidence of listed firms in Kenya. African Finance Journal, 17(1), 1-20.

Kormendi, R., \& Lipe, R. (1987). Earnings innovations, earnings persistence, and stock returns. Journal of Business, 60(3), 323345.

Kothari, S., Ramanna, K., \& Skinner, D. J. (2010). Implications for GAAP from an analysis of positive research in accounting. Journal of Accounting and Economics, 50(2-3), 246-286.

La Porta, R., Lopez-de-Silanes, F., Shleifer, A., \& Vishny, R. (2000). Investor protection and corporate governance. Journal of Financial Economics, 58(1), 3-27.

La Rocca, M. (2010). Is Ownership a Complement to Debt in Affecting Firm's Value. A Meta-Analysis (Working papers). University of Calabria (Italy).

Latif, K., Bhatti, A. A., \& Raheman, A. (2017). Earnings quality: A missing link between corporate governance and firm value. Business \& Economic Review, 9(2), 255-280.

Leland, H. E., \& Toft, K. B. (1996). Optimal capital structure, endogenous bankruptcy, and the term structure of credit spreads. The Journal of Finance, 51(3), 987-1019.

Leuz, C., \& Verrecchia, R. E. (2005). Firms' capital allocation choices, information quality, and the cost of capital. SSRN Electronic Journal, January 2005, 1-26. http://dx.doi.org/10.2139/ssrn.495363

Li, F., Abeysekera, I., \& Ma, S. (2014). The effect of financial status on earnings quality of Chinese-listed firms. Journal of Asia-Pacific Business, 15(1), 4-26.

Liebenberg, A. P., \& Hoyt, R. E. (2003). The determinants of enterprise risk management: Evidence from the appointment of chief risk officers. Risk Management and Insurance Review, $6(1), 37-52$.

Lin, F.-L. (2010). A panel threshold model of institutional ownership and firm value in Taiwan. International Research Journal of Finance and Economics, 42(1), 54-62.

Liow, K. H. (2010). Firm value, growth, profitability and capital structure of listed real estate companies: an international perspective. Journal of Property Research, 27(2), 119-146.

Lipe, R. (1990). The relation between stock returns and accounting earnings given alternative information. Accounting Review, 65(1), 49-71.

Lu, C.-W. (2012). Earnings Quality, Risk-taking and Firm Value: Evidence from Taiwan. International Proceedings of Economics Development and Research, 50(24), 119-123.

Maxwell, O., \& Kehinde, F. (2012). Capital structure and firm value: Empirical evidence from Nigeria. International Journal of Business and Social Science, 3(19).

Modigliani, F., \& Johnson, S. (1980). The Collected Papers of Franco Modigliani: The life cycle hypothesis of saving (Vol. 2). Cambridge, MA: MIT Press.

Modigliani, F., \& Miller, M. H. (1958). The cost of capital, corporation finance and the theory of investment. The American Economic Review, 48(3), 261-297.

Modigliani, F., \& Miller, M. H. (1963). Corporate income taxes and the cost of capital: a correction. The American Economic Review, 433-443.

Morck, R., Shleifer, A., \& Vishny, R. W. (1988). Management ownership and market valuation: An empirical analysis. Journal of Financial Economics, 20, 293-315.

Mule, R. K., Mukras, M. S., \& Nzioka, O. M. (2015). Corporate size, profitability and market value: An econometric panel analysis of listed firms in Kenya. European Scientific Journal, 11(13), 376-396.

Nam, H. J. (2019). The effect of ernings quality on financial analysts' dividend forecast accuracy: Evidence from Korea. Journal of Asian Finance, Economics and Business, 6(4), 9198. https://doi.org/10.13106/jafeb.2019.vol6.no4.91

Pandey, I. (2004). Financial Management (9th ed.). Indian Institute of Management. Ahmedabad, India: Vikas Publishing House P. VT. Ltd.

Penman, S. H., \& Zhang, X.-J. (2002). Accounting conservatism, the quality of earnings, and stock returns. The Accounting Review, 77(2), 237-264.

Pincus, M. (1983). Information characteristics of earnings announcements and stock market behavior. Journal of Accounting Research, 155-183.

Handoko, P. (2017). The Influence of Firm's Size, Growth, and Profitability on Firm Value with Capital Structure as the Mediator: A Study on the Agricultural Firms Listed in the Indonesian Stock Exchange. International Journal of Economics and Finance, 9(8), 103-110.

Nguyen, V. L., Dang, N. H., Dang, T. B., Vu, T. T. V., \& Nguyen, T. M. A. (2019). The Effects of Business Efficiency to Disclose Information of Sustainable Development: The Case of Vietnam. Asian Economic and Financial Review, 9(4), 547558.

Richardson, S. A., Sloan, R. G., Soliman, M. T., \& Tuna, A. (2001). Information in Accruals about the Quality of Earnings. 
SSRN Electronic Journal, July 2001, 1-52. http://dx.doi.org/10.2139/ssrn.278308

Rountree, B., Weston, J. P., \& Allayannis, G. (2008). Do investors value smooth performance? Journal of Financial Economics, 90(3), 237-251.

Sucuahi, W., \& Cambarihan, J. M. (2016). Influence of Profitability to the Firm Value of Diversified Companies in the
Philippines. Accounting and Finance Research, 5(2), 149.

Varaiya, N., Kerin, R. A., \& Weeks, D. (1987). The relationship between growth, profitability, and firm value. Strategic Management Journal, 8(5), 487-497.

Watts, R. L. (2003). Conservatism in accounting part I: Explanations and implications. Accounting Horizons, 17(3), 207-221. 